\title{
DETERMINATION OF HUMAN CYTOMEGALOVIRUS GENETIC DIVERSITY IN DIFFERENT PATIENT POPULATIONS IN COSTA RICA
}

\author{
Sara AHUMADA-RUIZ(1,3), Lizeth TAYLOR-CASTILLO(2), Kirsten VISONÁ(2), Ronald B. LUFTIG(2) \& Libia HERRERO-URIBE(1)
}

\begin{abstract}
SUMMARY
Seroprevalence of HCMV in Costa Rica is greater than 95\% in adults; primary infections occur early in life and is the most frequent congenital infection in newborns. The objectives of this study were to determine the genetic variability and genotypes of HCMV gB gene in Costa Rica. Samples were collected from alcoholics, pregnant women, blood donors, AIDS patients, hematologyoncology (HO) children and HCMV isolates from neonates with cytomegalic inclusion disease. A semi-nested PCR system was used to obtain a product of 293-296 bp of the gB gene to be analyzed by Single Stranded Conformational Polymorphism (SSCP) and sequencing to determine the genetic polymorphic pattern and genotypes, respectively. AIDS patients showed the highest polymorphic diversity with 14 different patterns while fifty-six percent of $\mathrm{HO}$ children samples showed the same polymorphic pattern, suggesting in this group a possible nosocomial infection. In neonates three genotypes (gB1, gB2 and gB3), were determined while AIDS patients and blood donors only showed one (gB2). Of all samples analyzed only genotypes gB1, 2 and 3 were determined, genotype gB2 was the most frequent (73\%) and mixed infections were not detected. The results of the study indicate that SSCP could be an important tool to detect HCMV intra-hospital infections and suggests a need to include additional study populations to better determine the genotype diversity and prevalence.
\end{abstract}

KEYWORDS: Human cytomegalovirus; Glycoprotein B; Polymerase chain reaction; Single stranded conformation polymorphism; Sequencing.

\section{INTRODUCTION}

Human Cytomegalovirus (HCMV) infection is generally asymptomatic in the immunocompetent individual although the virus persists in the host for life. However, severe infections with different clinical manifestations are common in immunocompromised patients with AIDS or chronic diseases and transplant recipients ${ }^{19}$. In these cases both primary and recurrent infections can induce severe illness, representing a major cause of morbidity and mortality with prolonged hospitalization and high costs ${ }^{6,26}$.

HCMV glycoprotein B ( $\mathrm{gB}$ ) gene is considered to be a multifunctional envelope component responsible for virion entry, cell to cell spread, syncytium formation ${ }^{18}$ and is the major target for neutralizing antibodies ${ }^{4,5}$. Based on sequence variation of the gB gene, HCMV strains can be classified into four $\mathrm{gB}$ genotype ${ }^{5}$ and recently, two new genotypes (gB6 and gB7) have been reported by TRINCADO et al. ${ }^{27}$. Genotype variation has been associated with cell tropism, viral pathogenesis and severity of disease. Several reports have suggested an association of different $\mathrm{gB}$ genotypes with pathogenicity $6,13,20,24,26,28,29$.

A follow-up study carried out in Costa Rica of 131 mothers and their newborn babies from birth to six years of age determined that $46 \%$ of the children seroconverted ( $\operatorname{IgM})$ during the first three months of life ${ }^{30}$. Another study ${ }^{12}$ demonstrated that HCMV was the most common cause of congenital disease, and since seroprevalence in Costa Rica is higher than $95 \%$ in adults, it is most likely that this infection is caused by reactivation and/or reinfection of the virus in the mother during pregnancy. Although cytomegalic inclusion disease is more likely in a seronegative pregnant woman who has a primary HCMV infection, HCMV congenital disease can also be found in infants born to women with recurrent disease as described by several authors ${ }^{3,17,23,25}$.

To further understand the diversity of HCMV and possible infectious routes, the SSCP has shown to be a valuable tool, since only one base pair (bp) change can affect the DNA Single stranded conformation and therefore its mobility in aclylamide electrophoresis; which reveals the different patterns ${ }^{8,9,10}$.

Since infection and reactivation of HCMV is very common in Costa Rica, the objectives of this study were to determine the genetic variability and genotypes of the virus circulating in the country using different study populations.

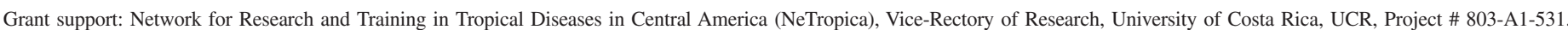
Louisiana State University-International Center for Medical Research and Training (LSU-ICMRT).

(1) Laboratory of Virology, Faculty of Microbiology, University of Costa Rica, San Jose, Costa Rica

(2) Louisiana State University-International Center for Medical Research and Training, San Jose, Costa Rica,

(3) Experimental and Applied Laboratory, Faculty of Natural Sciences and Technology, Department of Microbiology and Parasitology, University of Panama, Panama

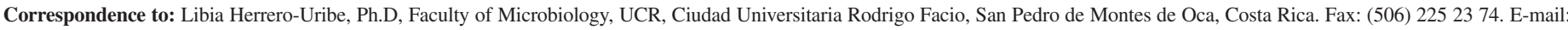
lherrero@ racsa.co.cr 


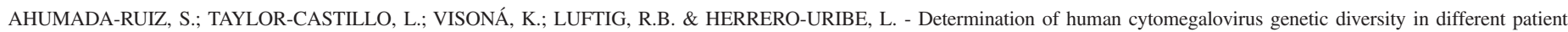
populations in Costa Rica. Rev. Inst. Med. trop. S. Paulo, 46(2):87-92, 2004.

\section{MATERIALS AND METHODS}

Study population: Samples available from different populations for HCMV prevalence studies were used, as follows: 41 Hematology/ oncology (HO) children, 30 AIDS patients, 30 alcoholics, 30 blood donors and 30 pregnant women were collected from 1998 to 2000 by the International Center for Medical Research and Training (ICMRT) and kept at $-70^{\circ} \mathrm{C}$. Sixteen HCMV isolates from neonates with congenital infection recovered in 1984 and control strains of genotype gB1 (Towne strain), gB2 (AD-169 strain) and gB3 (isolate from a clinical sample) were also tested. The neonate samples were kept frozen at the Virology Laboratory at the Faculty of Microbiology, University of Costa Rica (UCR) and the control samples were donated by Dr. Mia Britting from the Swedish Institute for Infection and Disease Control, Solna, Sweden. All study samples were assayed by nested PCR and this product was further analyzed by SSCP to determine the genetic diversity. Forty-five samples were selected for the genotype determination representing 23 different polymorphic SSCP patterns (Table 3).

HCMV-DNA extraction: HCMV-DNA was extracted from plasma by the Qiamp Blood kit (Qiagen, Chatsworth, CA) according to manufacture recommendations. DNA samples were re-suspended in 200 $\mu \mathrm{l}$ of water.

Amplification of HCMV-DNA: Polymerase Chain Reaction (PCR) was used to amplify a region of high sequence variability in the $\mathrm{gB}$ gene of HCMV as described by AQUINO \& FIGUEIREDO ${ }^{1}$ with minor modifications. The reaction mixture had a total volume of $50 \mu \mathrm{l}$, containing $10 \mu \mathrm{l}$ of DNA sample, $5 \mu \mathrm{l}$ of PCR 10x buffer, $2.5 \mathrm{mM}$ of $\mathrm{MgCl} 2,200 \mathrm{uM}$ each of the dNTPs and $1.6 \mathrm{pM} / \mu \mathrm{l}$ of primers $\mathrm{gB} 1319$ (5'TGGAACTGGAACGTTTGGC3') and gB1676 (5'TGACGCTGGTTTGGTTGATG3') ${ }^{26}$ and $2.5 \mathrm{U}$ of Taq DNA polymerase (Promega). Amplification of DNA was performed in a thermocycler (Perkin Elmer 9600) with a hot start of $94^{\circ} \mathrm{C}$ for 3 minutes, then 10 cycles of $94{ }^{\circ} \mathrm{C}$ for $30 \mathrm{sec}, 60{ }^{\circ} \mathrm{C}$ for $59 \mathrm{sec}$, followed by 30 cycles of $94{ }^{\circ} \mathrm{C}$ for $30 \mathrm{sec}, 55^{\circ} \mathrm{C}$ for $45 \mathrm{sec}, 72{ }^{\circ} \mathrm{C}$ for $59 \mathrm{sec}$ and a final extension of $72{ }^{\circ} \mathrm{C}$ for $3 \mathrm{~min}$. The amplified products of $357 \mathrm{bp}$ were visualized by electrophoresis in a $2 \%$ agarose gel stained with ethidium bromide.

A semi-nested PCR was performed in all samples to obtain an amplified product of 293-296 bp. The reaction mixture contained $1 \mu \mathrm{l}$ of the first round amplification product using the same concentrations of reagents as described above; but in a final volume of $40 \mu \mathrm{l}$. Primers used were $2.1 \mathrm{pM} / \mu \mathrm{l}$ of the $\mathrm{gB} 1319$ and $2.25 \mathrm{pM} / \mu \mathrm{l}$ of the $\mathrm{gB} 1604$ primer (5'GAAACGCGCGGCAATCGG3'). Amplification was carried out with 25 cycles at $94{ }^{\circ} \mathrm{C}$ for $30 \mathrm{sec}, 55^{\circ} \mathrm{C}$ for $45 \mathrm{sec}, 72{ }^{\circ} \mathrm{C}$ for $60 \mathrm{sec}$, and a final extension of $72^{\circ} \mathrm{C}$ for $3 \mathrm{~min}$.

Single Strain Conformation Polymorphism (SSCP): SSCP was performed according to TRINCADO et al. ${ }^{27}$. The principle of SSCP is a change in the electrophoretic mobility of the PCR product if there is a bp change that affects its secondary structure. This can be visualized by electrophoresis of a denaturalized PCR product in a polyacrylamide with the appearance of different polymorphic patterns related to the genetic diversity of each sample ${ }^{8,14}$. Five $\mu$ l of the double-stranded semi-nested PCR product was added to $5 \mu$ formamide buffer (formamide $100 \%$, bromophenol blue $0.02 \%$, xylene cyanol $0.02 \%$ and EDTA $10 \mathrm{mM}$ ). DNA was denatured at $94{ }^{\circ} \mathrm{C}$ for $10 \mathrm{~min}$, then cooled rapidly on ice; denatured samples were analyzed by electrophoresis on a $7 \%$ polyacrylamide gel (BIO-RAD) at 5 watts for 17 hours at room temperature using a vertical water-jacketed electrophoresis system (Life Technologies, Air Cooled System, and S2001). DNA was visualized by silver staining.

HCMV-DNA sequencing: Products of the semi-nested PCR were purified using the Wizard PCR Preps DNA purification Systems kit (Promega) and sequenced by the Big Dye Terminator kit (Applied Biosystems) in a 5\% acrylamide gel automatic sequencer (ABI model 373, Applied Biosystems).

The nucleotide sequences were edited by the BIOEDIT programme (www.mbio.ncsu.edu/BioEdit/bioedit.html) and aligned using the NCBI (National Center of Biotechnology Information) sequence database.

\section{RESULTS}

In PCR 1 a band of 357 bp was visualized and in the semi-nested PCR a band between 293-296 bp was seen (Fig. 1).

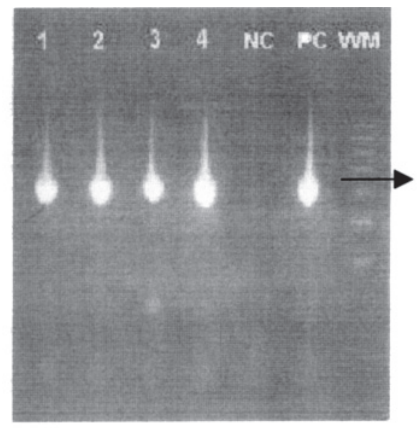

A

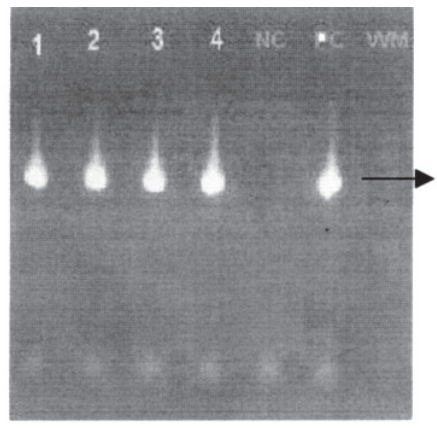

B
Fig. 1 - Electrophoresis in agarose gel of HCMV gB gene of PCR I products (A) (357 bp) and B PCR II (295-296 bp). Samples 1-4 are HCMV neonate isolations, NC: negative control, PC: positive control (HCMV, AD 169 strain), WM: weight marker.

A total of 53 polymorphic patterns were established in the 180 analyzed samples (Table 1). The group of AIDS patients presented the major genetic diversity with a total of 14 different patterns followed by the group of pregnant women with $10, \mathrm{HO}$ children with 8 , alcoholics with 7 , blood donors with 6 and HCMV isolates from neonates with 5. Control samples for $\mathrm{gB}$ genotypes showed a different polymorphic pattern for each one.

Figure 2 illustrates the results of the HO children, which showed a repetitive polymorphic pattern in 17 of the 30 analyzed samples characterized by the presence of two strong bands at the same positions in the gel. In these samples also weaker bands were observed that varied in intensity with some not being visible. These samples were classified under the same pattern, designed as 1A (Fig. 2). To confirm that this result was not due to contamination during PCR amplification or to the separation of the SSCP in the gel, the samples were re-analyzed, initiating with the extraction of DNA from the original sample. Furthermore, 14 additional samples were included from HO children (Costa Rica) and 5 samples from leukemia children from Nicaragua. The repeated samples all showed the same pattern A1 as well as 5 of the 14 additional samples from the $\mathrm{HO}$ children and 2 of the 5 from Nicaragua. 
Table 1

Distribution of techniques used to determine HCMV diversity in different study groups

\begin{tabular}{lcccc}
\hline Study group & PCR and SSCP & *Letters & $* *$ Pattern No. & Sequenced \\
\hline HO Children & 41 & A & $1-8$ & $1-14$ \\
AIDS patients & 30 & B & $1-7$ & 7 \\
Alcoholics & 30 & $\mathrm{C}$ & $1-6$ & 6 \\
Donors & 30 & $\mathrm{D}$ & $1-10$ & 8 \\
Pregnant women & 30 & $\mathrm{E}$ & $1-5$ & 6 \\
HCMV isolations & 16 & $\mathrm{~F}$ & $1-3$ & 3 \\
Reference strains & 3 & $\mathrm{R}$ & 53 & 45 \\
Total & 180 & & & \\
\hline
\end{tabular}

*Identification of each study group; **Total polymorphic patterns obtained from each study group

\section{Group A}

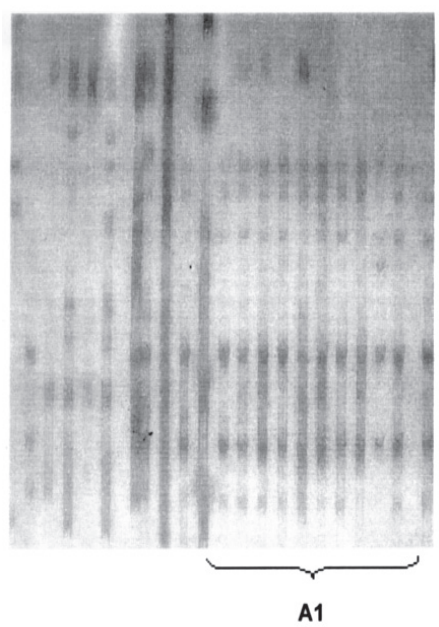

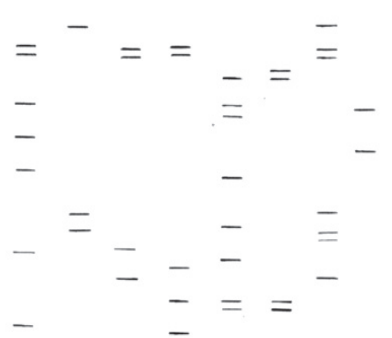

Fig. 2 - SSCP polymorphic patterns of Hematology/Oncology children (Group A), illustrated by the acrylamide electrophoresis bands (I) and the schematic presentation of each pattern (II).

Figure 3 illustrates the diversity of the polymorphic patterns of AIDS patients (bands I and II) and blood donors (III and IV) with 14 and 6 different patterns, respectively.

Of the 45 sequenced samples 37 were successfully genotyped and its distribution within the study groups is shown in Table 2. Of the remaining 8 samples, the genotype could not be determined since sequenced products were not suitable for this procedure.

Of the six analyzed study groups, neonates were the only group that showed HCMV genotypes gB1, gB2 and gB3. Pregnant women showed genotypes gB1 and gB2; HO children and alcoholics showed genotypes $\mathrm{gB} 2$ and gB3, while AIDS patients and blood donors only showed genotype gB2. However, great difference between these two last groups was detected regarding frequency of polymorphic patterns with the presence of 14 and 6 patterns, respectively (Fig. 3). The three control sample patterns corresponded to gB1 (Towne strain) gB2 (strain AD169) and gB3 (Table 2). In alcoholics and neonate isolates, two samples with identical polymorphic patterns were found to have different genotypes (Table 3).
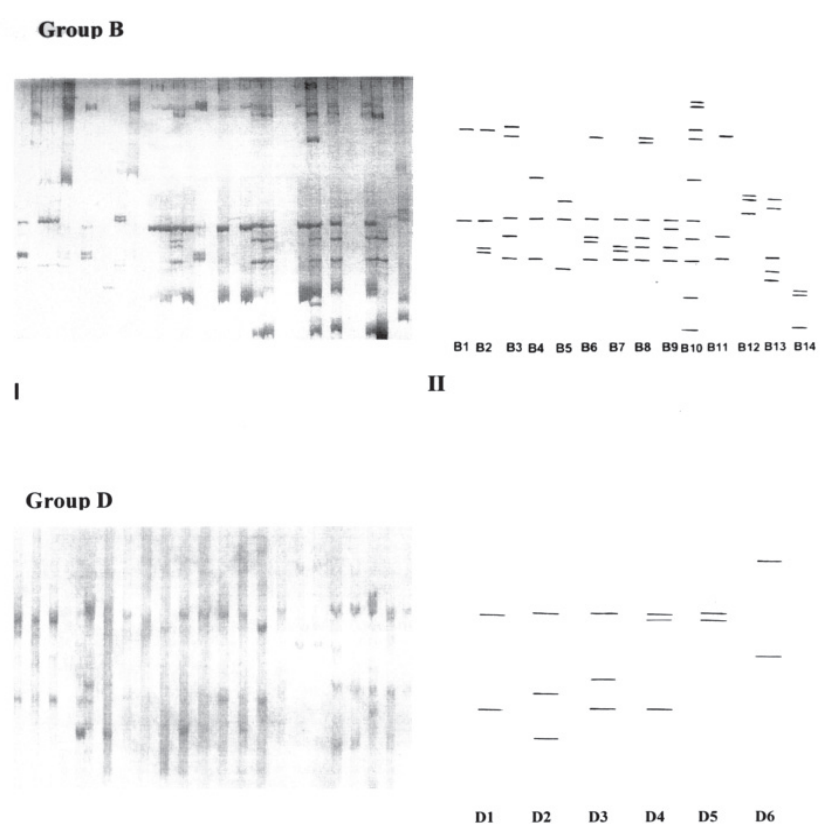

III

IV

Fig. 3 - SSCP polymorphic patterns of AIDS patients (Group B) and Blood Donors (Group D), illustrated by the acrylamide electrophoresis bands (I and III) and the schematic presentation of each pattern (II and IV), respectively.

The distribution of genotypes in the 37 samples were as follows: 27 samples with gB2 (73\%), 6 samples with gB1 (16\%), 4 samples with gB3 $(11 \%)$ and none of these samples had mixed infection. Overall genotype gB2 was the most frequent $(73 \%)$ and had the greatest genetic variability, followed by genotype gB3 and genotype gB1 (Table 3).

\section{DISCUSSION}

A semi-nested PCR method was applied to obtain the largest number of positive samples, since this procedure increase both sensitivity and specificity. SSCP analysis was used to characterize genetic variations among the study populations ${ }^{9,15}$ because this method has shown to be both sensitive and simple. A change in nucleotide can easily be detected 


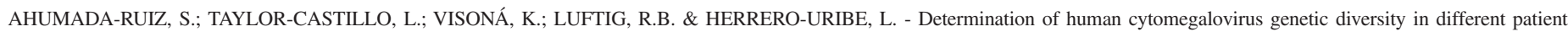
populations in Costa Rica. Rev. Inst. Med. trop. S. Paulo, 46(2):87-92, 2004.

Table 2

Distribution of HCMV gB genotypes within the study groups

\begin{tabular}{|c|c|c|c|c|c|}
\hline \multirow[b]{2}{*}{ Study group } & \multirow[b]{2}{*}{ *Analyzed samples } & \multicolumn{4}{|c|}{ Genotypes } \\
\hline & & $\mathrm{gB} 1$ & $\mathrm{gB} 2$ & gB3 & $\mathrm{gB} 4$ \\
\hline HO Children & 8 & & 4 & 1 & \\
\hline AIDS patients & 7 & & 4 & & \\
\hline Alcoholics & 6 & & 4 & 1 & \\
\hline Donors & 8 & & 7 & & \\
\hline Pregnant women & 6 & 2 & 4 & & \\
\hline HCMV isolations & 7 & 3 & 3 & 1 & \\
\hline Reference strains & 3 & 1 & 1 & 1 & \\
\hline Total & $* 45$ & 6 & 27 & 4 & \\
\hline
\end{tabular}

* Of 45 samples sequenced, 37 could be genotyped and 8 were not able to be edited

Table 3

HCMV polymorphic patterns according to genotypes in the different study groups

\begin{tabular}{lcc}
\hline Study population & Polymorphic patterns & Genotypes \\
\hline HO children & A1 & gB2 \\
AIDS patients & A5 & gB3 \\
Alcoholics & B1, B3, B5 & gB2 \\
Donors & C1, C2, $*$ C6 & gB2 \\
Pregnant women & D1, D2, D3 & gB3 \\
& D4, D5, D6 & gB2 \\
HCMV isolations & E3 & gB1 \\
& E1, E2 & gB2 \\
Reference strains & $*$ F2, F4 & gB1 \\
& F1, $*$ F2, & gB2 \\
& F3 & gB3 \\
& R4 & gB2 \\
& R5 & gB3 \\
\hline
\end{tabular}

* The same letters and numbers identify equal polymorphic patterns

by SSCP, if this alters the secondary structure of the molecule. Therefore, SSCP has the advantage compared to other techniques such as restriction fragment polymorphism (RFP) that it is able to detect variations throughout the amplified product ${ }^{16}$. Its sensitivity depends mainly on the size of the DNA fragment ${ }^{11}$ and is decreased when the size is larger than $530 \mathrm{pb}^{7}$. The SSCP fragments in this study were 293-296 bp and 53 different polymorphic patterns were detected in 180 samples.

SSCP has been used for other pathogens (HBV and HCV), showing that from donor to recipient and mother to neonate the SSCP pattern was conserved as well as in patients affected by nosocomial outbreaks in oncology and hemodyalisis units ${ }^{9,10,11}$.

In 41 samples analyzed from the HO children using SSCP 24 showed the same polymorphic pattern A1. The hospitalization period among children with patterns different from A1 were relatively short ( $<40$ days). However, in children with pattern A1, although information regarding hospitalization was incomplete, there was a tendency for it to be over longer periods. Therefore, we speculate that the high frequency of one pattern could be related to nosocomial infections, which is further supported by the fact that the same genotype was established in all samples with pattern A1 (gB2).

The group of AIDS patients had the major amount of polymorphic patterns with one genotype (gB2). This could be related to differences in active replication of HCMV in each of these groups, considering that AIDS patients frequently show pathologies related to HCMV active infection and reactivation/reinfection of immunocompromised patients has been well documented ${ }^{19}$. The AIDS patients results were similar to those reported by BALE et al. ${ }^{2}$, RASMUSSEN et al. ${ }^{21}$, ROSEN et al. ${ }^{22}$, WOO et al..$^{29}$ in showing the presence of genotype gB2. On the contrary, blood donors showed few polymorphic patterns probably related to a latent disease state, also with only the presence of genotype gB2.

Two situations were observed where different genotypes had the same polymorphic patterns, showing that the difference of bp's related to genotypes did not cause structural changes.

None of the samples had mixed HCMV infections, different from the results reported by AQUINO \& FIGUEIREDO ${ }^{1}$. They found different genotypes according to the site of infection and specimen, which suggests a cellular tropism among different genotypes. Therefore, the use of only plasma samples as in this study do not allow us to make final conclusions about the mixed infections in these populations.

In conclusion SSCP method showed a high sensitivity for detection of genetic variations in the samples analyzed (53/180), but maybe even more important was the capacity to identify equal polymorphic patterns that relates to the same origin and therefore could be an indication of nosocomial infection. The results obtained show the need to carry out further studies focusing on a possible nosocomial infection at the National Children's Hospital, to determine if strain A1 is of dominant circulation within the hospital and also to evaluate its possible resistance to the antiviral drugs currently in use.

The data show the predominance of HCMV genotype gB2 in Costa Rica among the study groups, with its limitations regarding the number of total individuals analyzed and the type of samples used (only plasma). In the future this study should be amplified including a more diverse study population and collection of different specimens from each participant with an approach of longitudinal studies.

\section{RESUMEN}

\section{Determinación de la diversidad genética del citomegalovirus humano en diferentes poblaciones de pacientes en Costa Rica}

La seroprevalencia de citomegalovirus es mayor del $95 \%$ en la población adulta de Costa Rica; la infección primaria ocurre muy temprano en la vida y es la infección congénita más frecuente en recién nacidos. El objetivo de este trabajo fue determinar la variabilidad genética y los genotipos del gene gB del citomegalovirus humano. Se recolectaron muestras de sangre de mujeres embarazadas, alcohólicos, pacientes con 


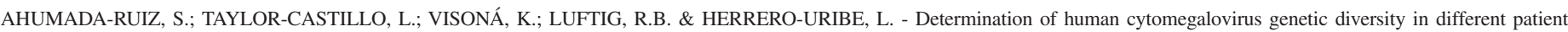
populations in Costa Rica. Rev. Inst. Med. trop. S. Paulo, 46(2):87-92, 2004.

SIDA, niños con trastornos hemato-oncológicos, donadores de sangre y se incluyeron aislamientos de citomegalovirus de neonatos con enfermedad congénita. Se utilizó un sistema de PCR semi-anidado para obtener una banda de 293-296 pares de bases, la cual fue analizada por la técnica de Polimorfismo conformacional de banda simple (PCBS) y secuenciada para determinar los patrones genéticos polimórficos y los genotipos, respectivamente. La mayor diversidad polimórfica se encontró en los pacientes con SIDA con 14 patrones diferentes mientras que en los niños con trastornos hemato-oncológicos se demostró el mismo patrón en el 56\% de los casos, sugiriendo una posible infección nosocomial en este grupo. En los neonatos se encontraron tres genotipos (gB1, gB2, gB3) mientras que en los pacientes con SIDA y en los donadores de sangre solo se demostró el gB2. En las muestras analizadas se determinaron los genotipos gB1, gB2 y gB3 y el gB2 se determinó en el $73 \%$ de los casos, no se detectaron infecciones mixtas. Los resultados de este trabajo indican que la técnica del PCBS puede ser una herramienta importante para detectar el citomegalovirus humano en infecciones intrahospitalarias y se sugiere la importancia de incluir poblaciones de estudio adicionales para determinar mejor la diversidad genética y su prevalencia.

\section{ACKNOWLEDGEMENTS}

The authors thank The Costa Rican Social Security System, the Institute of Alcoholics and Drug Abuse, Costa Rica and Dr. Mia Britting from the Swedish Institute for Infection and Disease Control, Sweden, who kindly facilitated the study and reference samples, respectively. Andreas Busse, MS from the Center of Investigation in Molecular and Cell Biology, UCR and Carlos Vargas from the LSU-ICMRT for technical assistance. Ms. Virginia Larrad from the LSU-ICMRT for supporting the preparation of the manuscript and Mrs. Xinia Arias from the Faculty of Microbiology, UCR for secretarial support.

\section{REFERENCES}

1. AQUINO, V.H. \& FIGUEIREDO, L.T. - High prevalence of renal transplant recipient infected with more than one cytomegalovirus glycoprotein B genotype. J. med. Virol., 61: $138-142,2000$.

2. BALE Jr., J.F.; MURPH, J.R.; DEMMLER, G.J. et al. - Intrauterine cytomegalovirus infection and glycoprotein B genotypes. J. infect. Dis., 182: 933-936, 2000.

3. BENSHUSHAN, A.; BRZEZINSKI, A.; BEN-DAVID, A. \& NADJARI, M. - Early recurrent CMV infection with severe outcome to the fetus. Acta obstet. gynec. scand., 77: 694-695, 1998.

4. BRITT, W.J.; VUGLER, L.; BUTFILOSKI, E.J. \& STEPHENS, E.B. - Cell surface expression of human cytomegalovirus (HCMV) gp55-116 (gB): use of HCMV recombinant vaccinia virus-infected cells in analysis of the human neutralizing antibody response. J. Virol., 64: 1079-1085, 1990.

5. CHOU, S.W. \& DENNISON, K.M. - Analysis of interstrain variation in cytomegalovirus glycoprotein B sequences encoding neutralization-related epitopes. J. infect. Dis., 163: 1229-1234, 1991.

6. FRIES, B.C.; CHOU, S.; BOECKH, M. \& TOROK-STORB, B. - Frequency distribution of cytomegalovirus envelope glycoprotein genotypes in bone marrow transplant recipients. J. infect. Dis., 169: 769-774, 1994.

7. GASSER, R.B. \& ZHU, X.Q. - Sequence-based analysis of enzymatically amplified DNA fragments by mutation detection techniques. Parasit. today, 15: 462-465, 1999.
8. HALL, J.S.; FRENCH, R.; MORRIS, T.J. \& STENGER, D.C. - Structure and temporal dynamics of populations within wheat streak mosaic virus isolates. J. Virol., 75: 10231-10243, 2001.

9. HARDIE, D.R.; KANNEMEYER, J. \& STANNARD, L.M. - DNA single strand conformation polymorphism identifies five defined strains of hepatitis B virus (HBV) during an outbreak of HBV infection in an oncology unit. J. med. Virol., 49: 49-54, 1996.

10. HARDIE, D.R. \& WILLIAMSON, C. - Analysis of the preS1 gene of hepatitis B virus (HBV) to define epidemiologically linked and un-linked infections in South Africa. Arch. Virol., 142: 1829-1841, 1997.

11. HENEINE, W.; SWITZER, W.M.; BUSCH, M.; KHABBAZ, R.F. \& KAPLAN, J. Molecular subtyping of human T-cell lymphotropic virus type 2 by single-strand conformation polymorphism analysis. Retrovirus Epidemiology Study Group. J. clin. Microbiol., 33: 3260-3263, 1995.

12. HERRERO, L.; ZAMORA, E.; ECHEVERRÍA, F. \& SAÉNZ, A. - Infección citomegálica del recién nacido. Rev. costarric. Cienc. med., 7: 137-143, 1988.

13. LUKÁCSI, A.; TARODI, B.; ENDREFFY, E. et al. - Human cytomegalovirus gB genotype 1 is dominant in congenital infections in South Hungary. J. med. Virol., 65: 537$542,2001$.

14. MAYRAND, M.-H.; COUTLÉE, F.; HANKINS, C. et al. - Detection of the human papillomavirus type 16 DNA in consecutive genital samples does not always represent persistent infection as determined by molecular variant analysis. The Canadian Women's HIV Study Group and M. Roger. J. clin. Microbiol., 38: 3388-3393, 2000.

15. MEYER-KONIG, U.; HABERLAND, M.; VON LAER, D.; HALLER, O. \& HUFERT, F.T. - Intragenic variability of human cytomegalovirus glycoprotein B in clinical strains. J. infect. Dis., 177: 1162-1169, 1998.

16. MORI, C.; TAKAHARA, R.; TORIYAMA, T. et al. - Identification of the Oka strain of the live attenuated varicella vaccine from other clinical isolates by molecular epidemiologic analysis. J. infect. Dis., 178: 35-38, 1998.

17. MORRIS, D.J.; SIMS, D.; CHISWICK, M. et al. - Symptomatic congenital cytomegalovirus infection after maternal recurrent infection. Pediat. infect. Dis. J., 13: 61-64, 1994.

18. NAVARRO, D.; PAZ, P.; TUGIZOV, S. et al. - Glycoprotein B of human cytomegalovirus promotes virion penetration into cells, transmission of infection from cell to cell, and fusion of infected cells. Virology, 197: 143-158, 1993.

19. PASS, R.F. - Cytomegalovirus. In: KNIPE, D.M. \& HOWLEY, P.M., ed. Fields Virology. 4. ed. Philadelphia, Lippincott Williams and Wilkins, 2001. v. 2, p. 2675-2705.

20. PEEK, R.; VERBRAAK, F.; BRUINENBERG, M. et al. - Cytomegalovirus glycoprotein B genotyping in ocular fluids and blood of AIDS patients with cytomegalovirus retinitis. Invest. Ophthal. vis. Sci., 39: 1183-1187, 1998.

21. RASMUSSEN, L.; HONG, C.; ZIPETO, D. et al. - Cytomegalovirus gB genotype distribution differs in human immunodeficiency virus-infected patients and immunocompromised allograft recipients. J. infect. Dis., 175: 179-184, 1997.

22. ROSEN, H.; CORLESS, C.L.; RABKIN, J. \& CHOU, S. - Association of cytomegalovirus genotype with graft rejection after liver transplantation. Transplantation, 66: 1627$1631,1998$.

23. ROUSSEAU, T.; DOUVIER, S.; REYNAUD, I. et al. - Severe fatal cytomegalic inclusion disease after documented maternal reactivation of cytomegalovirus infection during pregnancy. Prenat. Diagn., 20: 333-336, 2000.

24. SHEPP, D.H.; MATCH, M.E.; ASHRAF, A.B. et al. - Cytomegalovirus glycoprotein B groups associated with rinitis in AIDS. J. infect. Dis., 174: 184-187, 1996. 
AHUMADA-RUIZ, S.; TAYLOR-CASTILLO, L.; VISONÁ, K.; LUFTIG, R.B. \& HERRERO-URIBE, L. - Determination of human cytomegalovirus genetic diversity in different patient populations in Costa Rica. Rev. Inst. Med. trop. S. Paulo, 46(2):87-92, 2004.

25. STAGNO, S.; PASS, R.F.; DWOVSKY, M.E. \& ALFORD Jr., C.A. - Maternal cytomegalovirus infection and perinatal transmission. Clin. Obstet. Gynec., 25: 563$576,1982$.

26. TOROK-STORB, B.; BOECKH, M.; HOY, C. et al. - Association of specific cytomegalovirus genotypes with death from myelosuppression after marrow transplantation. Blood, 90: 2097-2102, 1997.

27. TRINCADO, D.E.; SCOTT, G.M.; WHITE, P.A. et al. - Human cytomegalovirus strain associated with congenital and perinatal infections. J. med. Virol., 61: 481-487, 2000 .
28. VOGELBERG, C.; MEYER-KONIG, U.; HUFERT, F.T.; KIRSTE, G. \& VON LAER, D. - Human cytomegalovirus glycoprotein B genotypes in renal transplant recipients. J. med. Virol., 50: 31-34, 1996.

29. WOO, P.; LO, C.-Y.; LO, S. et al. - Distinct genotypic distributions of cytomegalovirus (HCMV) envelope glycoprotein in bone marrow and renal transplant recipients with HCMV disease. Clin. Diag. Lab. Immunol., 4: 515-518, 1997.

30. ZAMORA, E.; HERRERO, L. \& MORALES, C. - Cytomegalovirus in non A, non B hepatitis. In: VILLAREJOS, V.M., ed. Proceedings of the International Symposium on Viral Hepatitis and AIDS. San José Costa Rica, Trejos Hnos., 1987. p. 273-278.

Received: 4 September 2003

Accepted: 8 March 2004 